\title{
Identification of Lactobacillus proteins with different recognition patterns between immune rabbit sera and nonimmune mice or human sera
}

\author{
Sabina Górska ${ }^{*}$, Barbara Buda$^{2}$, Ewa Brzozowska ${ }^{1}$, Martin Schwarzer ${ }^{3}$, Dagmar Srutkova ${ }^{3}$, Hana Kozakova $^{3}$
} and Andrzej Gamian'

\begin{abstract}
Background: The genus Lactobacillus belongs to a large heterogeneous group of low G + C Gram-positive anaerobic bacteria, which are frequently used as probiotics. The health-beneficial effects, in particular the immunomodulation effect, of probiotics depend on the strain and dose used. Strain variations may be related to diversity of the cell surface architecture of bacteria and the ability to express specific antigens or secrete compounds. The use of Lactobacillus as probiotic requires a comprehensive understanding of its effect on host immune system. To evaluate the potential immunoreactive properties of proteins isolated from four Lactobacillus strains: L. johnsonii 142 and L. johnsonii 151, L. rhamnosus LOCK 0900 and L. casei LOCK 0919, the polyclonal sera obtained from mouse and human have been tested as well as with sera from rabbits immunized with whole lactobacilli cells.

Results: The reactivity of isolated proteins detected by SDS-PAGE and Western blotting was heterogeneous and varied between different serum samples. The proteins with the highest immunoreactivity were isolated, purified and sequenced, in particular the fractions were identified as phosphoglycerate kinase (L. johnsonii 142), glyceraldehyde 3phosphate dehydrogenase (L. johnosnii 142, L. rhamnosus LOCK 0900), hypothetic protein JDM1_1307 (L. johnsonii 151) and fructose/tagatose-bisphosphate-aldolase (L. casei LOCK 0919).

Conclusion: The different prevalence of reactions against tested antigens in rabbit, mouse and human sera may indicate significant differences in immune system and commensal cross-talk in these groups. The identification of immunoreactive lactobacilli proteins opens the possibility to use them as an antigens for development of vaccines.
\end{abstract}

Keywords: Lactobacillus, Probiotics, Surface proteins, Immunoreactivity, Sera

\section{Background}

Lactobacillus are nonpathogenic Gram-positive bacteria that form part of the normal intestinal microbiome in humans and animals. They are a large group of bacteria growing under microaerophilic conditions for optimal growth temperature in the range of $30-40{ }^{\circ} \mathrm{C}$ and pH 5.5-6.2 typically. The Lactobacillus species are commonly used to manufacture fermented milk products

\footnotetext{
* Correspondence: sabina.gorska@iitd.pan.wroc.pl

${ }^{1}$ Department of Medical Microbiology, Ludwik Hirszfeld Institute of Immunology and Experimental Therapy of the Polish Academy of Sciences, Wroclaw, Poland

Full list of author information is available at the end of the article
}

and some of them are considered probiotics on account of their health benefits [1-5]. Moreover, they are "generally regarded as safe" according to The American Food and Drug Administration due to their long history of safe use in fermented foods and their presence in the normal intestinal and urogenital microbiome of humans. The mechanisms underlying probiotic effect are generally attributed to the interaction of probiotics with other microorganisms (bacteria-bacteria cross-talk) or with host cells (bacteria-host cross-talk). The interactions depend on the viability of probiotic cells, since it is exerted by competitive exclusion, direct inhibition of certain 
microorganisms involving production of antimicrobial molecules or increased growth of healthy components of the microbiota, while the interaction with the host is based on the capacity of host cells to recognize specific bacterial components or products, giving rise to response that commonly involve the immune system [6].

The lactic acid bacteria influence has been described as enhancement of non-specific immunity as well as adjuvant and immunoregulatory effects in adaptive immune responses. However, the bacterial components responsible for these effects are often left unidentified. The Lactobacillus bacteria show great diversity in the cell surface architecture which may influence to the physicochemical properties of the bacterial cell and strain specific properties. The cell envelope of lactobacilli is composed of the bilayer lipid cell membrane with embedded proteins anchored to the cell wall and covered by thick multilayered peptidoglycan together with lipo- and teichoic acids, pili and polysaccharides sheet. Polysaccharides can either attach to the cell surface like an outer capsule and often be covalently bound to Nacetylmuramic acid of peptidoglycan or be loosely attached with it or be secreted to the surrounding environment.

The cell surface proteins are anchored to the cell wall by various mechanisms or released into the surrounding medium, where they reassociate with the cell wall through electrostatic interactions [7]. Covalently anchored proteins can be divided into $\mathrm{N}$ - or C-terminally anchored proteins, lipoproteins and LPXTG-anchored proteins (or sortase-dependent proteins). N-terminally anchored proteins are involved in extracellular transport, signal transduction and protein turnover, while lipidanchored proteins are involved in adhesion, antibiotic resistance, folding and translocation of proteins [8-10]. LPXTG-anchored proteins have been demonstrated to be crucial for the interactions of pathogenic and nonpathogenic bacteria with their hosts [11]. Some species of lactobacilli produce an additional paracrystalline layer of proteins called as $\mathrm{S}$-layer. This is a two-dimensional crystal layer consisting of $25-71 \mathrm{kDa}$ molecular mass proteins mainly and highly predicted overall $\mathrm{p} I$ value (9.4-10.4), and represent $10-15 \%$ of the total cell protein content [12-14]. The lattice symmetry of Lactobacillus S-layer proteins is of oblique or hexagonal type [15]. The most often proposed function for S-layer is mainly reduction the ability of pathogens adhesion and invasion or reduction theirs toxins activity $[4,5,16-19]$. Some other cell surface proteins were also shown to be involved in adhesion to human intestinal cells and mucins, stimulation of cytokine secretion and mediation of co-aggregation of probiotic bacteria with pathogenic bacteria [20]. Pili have been identified at the genome level in some lactobacilli, however only in L. rhamnosus
GG polymeric structures and functionality have been characterized [21]. The flagella have been recognized only in twelve species of lactobacilli, and comprises flagellin, protein which is suggested to activate of signaling pathways and modulate of host immune cells [22].

The other key molecules are extracellular proteins which could regulate certain signaling pathways and cellular responses, including secretion of different effector molecules such chemokines, cytokines, antibacterial peptides, mucus secretion, induction of changes in the surface properties and modulation of the immune function and the immune response of the host cells [23]. It is known that Lactobacillus bacteria interact with epithelial cells trough several mechanisms mediated by extracellular and cell-surface-associated proteins that bind to mucus and intestinal cells [24]. Lactobacillus adhesion to mucus involves mucus binding proteins (Mubs) which in addition to the same domain organization typical for cell surface proteins share a mucus binding domain [25]. The MucBPs (putative mucus binding proteins) have been found among 13 different Lactobacillus strains [26]. L. fermentum produced a $32 \mathrm{kDa}$ surface-associated protein (32-mMubp) that is suggested to mediate adhesion to mucus [27], whereas studies with L. rhamnousus GG have shown a mucus binding factor with a presumed ancillary involvement in pilus-meditative mucosal adhesion [28]. Recent studies of L. casei BL23 sortase have shown that this sortase might be involved in adhesion of this strain to Caco-2 and HT cells [29]. L. johnsonii has been found to produce elongation factor $\mathrm{Tu}$ (EF-Tu) which mediated the attachment to human intestinal cells and mucins [20]. The issue of lactobacilli antigens supporting probiotic action in probiotic bacteria has been extensively reviewed by Lebeer et al. [30, 31], by Kleerebezem et al. [10] and by Sengupta et al. [32], however studies on the immunoreactivity of the lactobacilli molecules are sparse. In our previous studies of two structurally different exopolysaccharides isolated from $L$. johnsonii 142 and L. johnsonii 151 [33, 34] we have shown that both antigens differed in their reactivity with human sera. It appeared that physiological sera of healthy adult blood donors contain antibodies reactive with studied exopolysaccharides, at relatively high titers. Moreover, such antibodies are also present in human umbilical cord blood sera.

The aim of this study was to identify immunoreactive proteins of four Lactobacillus strains: L. johnsonii 142 and L. johnsonii 151, L. rhamnosus LOCK 0900 and $L$. casei LOCK 0919. The proteins immunoreactivity with 13 sera (from mice, from human healthy adults, human umbilical cord blood sera and from rabbits immunized with cells) was detected by SDS-PAGE and Western blotting. As a result, several major immunoreactive proteins were identified. 


\section{Results}

The protein concentration in extracts of the studied strains was significantly different and varied, ranging from 3.1 to $18.7 \mathrm{mg} / \mathrm{mL}$. We observed that extraction of protein with sodium dodecyl sulfate procedure was no effective in case of L. rhamnosus LOCK900, probably due to the presence of polysaccharide slime produced by these bacteria. Thus the slime has been removed mechanically which allowed to increase the efficiency of the protein extraction by $300 \%$. Samples were electrophoresed and stained with Coomassie Brilliant Blue. The representative results are shown in Fig. 1. It could be demonstrated that proteins ranged in molecular mass from > $100 \mathrm{kDa}$ to about $20 \mathrm{kDa}$. The profiles were quite variable, emphasizing the heterogeneity in species, however it has been shown to share several predominant bands.

For the analysis of immunoreactivity, protein samples were transferred to a polyvinylidene difluoride membrane for immunoblotting. This experiment resulted in a detection of proteins reacting with analyzed sera and several delineations were revealed. In case of L. johnsonii 142, there were five protein bands with the molecular mass of about $90,67,50,25$ and $18 \mathrm{kDa}$ reacting with homologous sera (Fig. 2, s3, line 1), two immunoreactive protein fractions reacting with sera against $L$. animalis

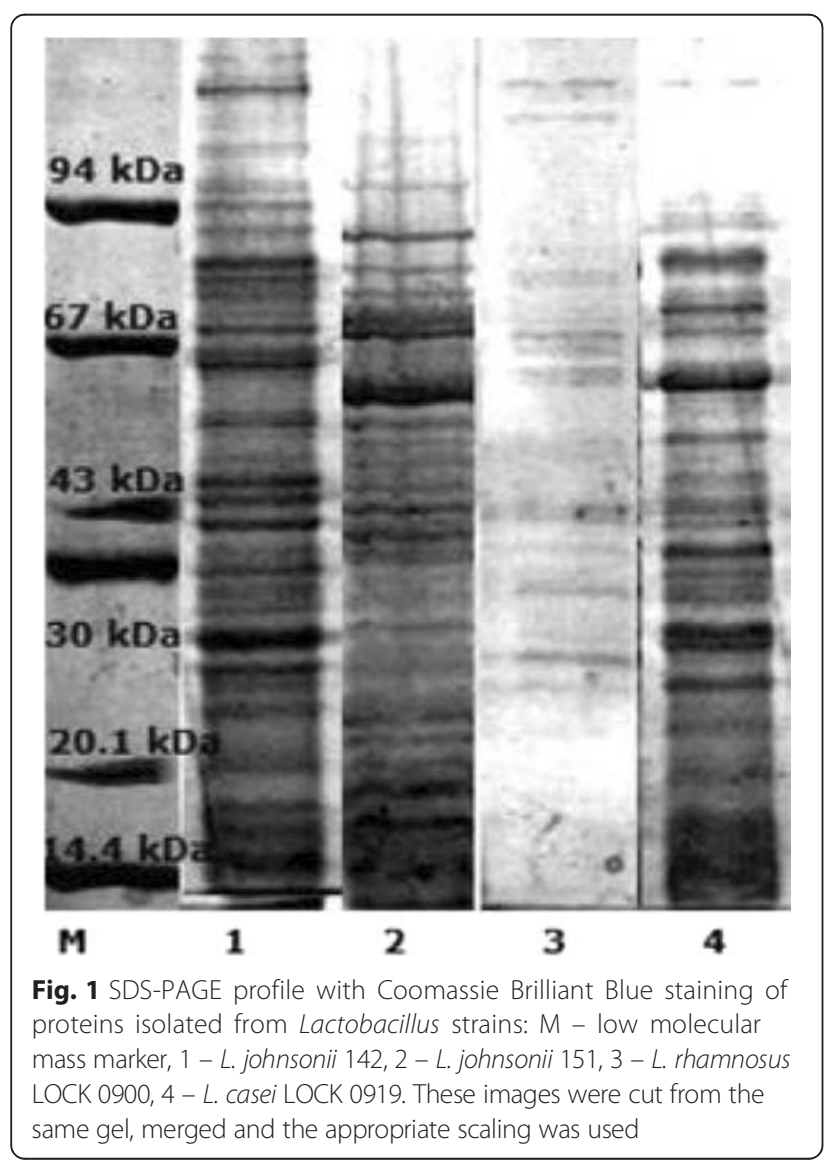

murinus 148 (ca. 67 and 43 kDa, Fig. 2, s2, line 1), six major protein fractions reacting with sera against $L$. johnsonii 151 (ca. 90, 67, 53, 43, 38 and 35 kDa, Fig. 2, s4, line 1) and several proteins ca. $67,43,30 \mathrm{kDa}$ reacting with sera against L. paracasei LOCK 0912 (Fig. 2, s1, line 1). We detected a marked reaction of protein about $30 \mathrm{kDa}$ with sera from mouse kept under specificpathogen-free conditions (SPF conditions, Fig. 2, s6, line 1) and with mouse kept under conventional conditions (Fig. 2, s7, line 1), however there were no reactions with sera obtained from germ free mouse (Fig. 2, s5, line 1). The antibodies against protein $35 \mathrm{kDa}$ were detected in several human sera, namely s8-s10 and one umbilical cord blood serum (s11), but the reaction was very weak. In case of protein extract from $L$. johnsonii 151 we observed several immunoreactive proteins, however homologous reactivity was blurred (Fig. 2, s4, line 2) and enabling determination of the approximate molecular mass. Strain 151 produced small proteins (ca $40 \mathrm{kDa}$ ) which reacted with other rabbit sera (Fig. 2, s1-s3, line 2 ), and very weak with human sera (Fig. 2, s8-s13, line 2 ). We didn't observe reactivity with sera from mice (Fig. 2, s5-s7, line 2). Considering human origin species L. casei LOCK 0919 we observed a broad reactivity of protein with molecular mass of about $90 \mathrm{kDa}$, in particular, as the only one of the tested bacterial proteins reacted clearly with human umbilical cord blood sera (Fig. 2, s8-s10, line 4). Weak cross-reactivity with mouse serum has been noticed for proteins of molecular mass of 30 and $43 \mathrm{kDa}$ isolated from LOCK 0900 (Fig. 2, s7, line 4). Interestingly, six proteins of LOCK 0900 and LOCK 0919 have been shown to cross-react with serum against L. johnsonii 142 (Fig. 2, s3, lines 3-4).

To identify the most immunogenic/immunoreactive proteins, electrophoretic preparation of isolated proteins from four analyzed strains was made using Prep-Cell Apparatus (491 model Bio-Rad) and re-analyzed in the immunoblotting assays. The representative results were shown on Figs. 3 and 4. Bands with molecular mass of about $20 \mathrm{kDa}$ (immunoreactive with serum against $L$. johnsonii 142) and 38, 40, $42 \mathrm{kDa}$ (reacting with rabbit, human or mouse sera) isolated from L. johnsonii 142, one spot of $45 \mathrm{kDa}$ from L. johnsonii 151 (reacting with rabbit sera against $L$. johnsonii 151 and human sera), and two bands of 35 and $50 \mathrm{kDa}$ from L. rhamnousus LOCK 0900 and also two bands of 30 and $50 \mathrm{kDa}$ isolated from L. casei LOCK 0919 showing strong immunoreactivity features were cut from the gel and analyzed in LC-MS/MS. Proteins were identified by comparative analysis of peptides masses (NCBI, UniProt databases) using MASCOT and statistical analysis. These procedures failed to obtain and identify the most reactive protein $(90 \mathrm{kDa})$ in extract of LOCK 0919. The results of sequencing and most like homologies of isolated and 


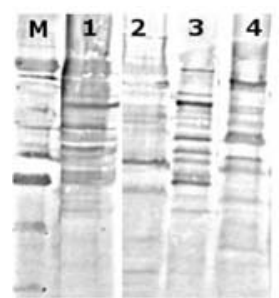

s1

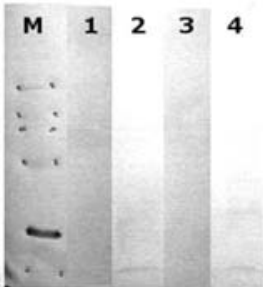

s5

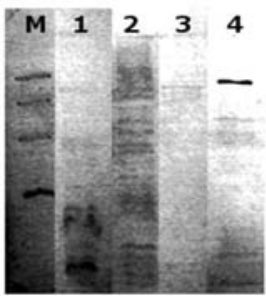

s8

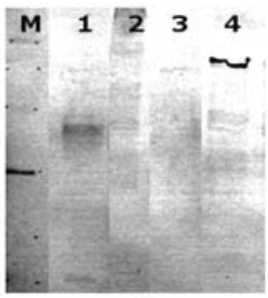

s11

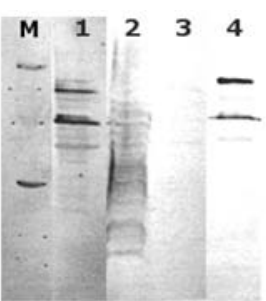

s2

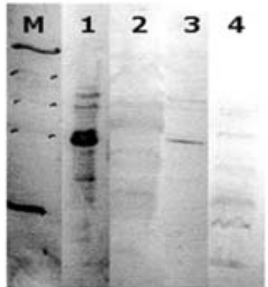

s6

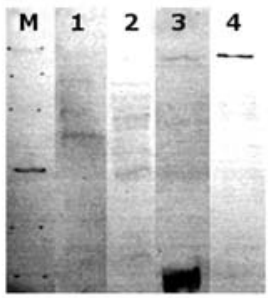

s9

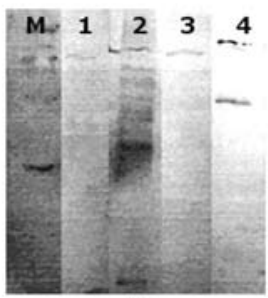

s12

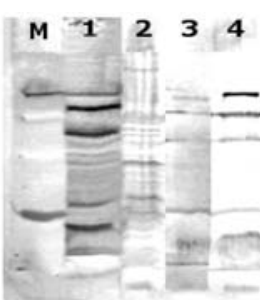

s3

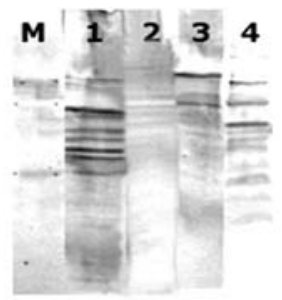

s4

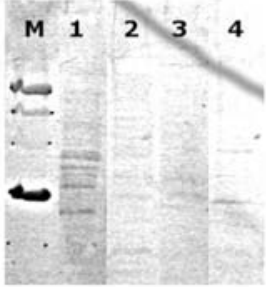

s7

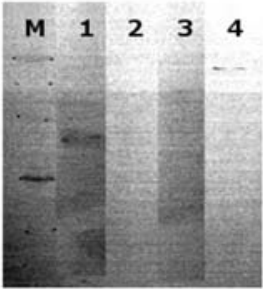

s10

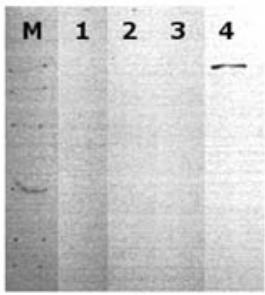

s13

Fig. 2 Immunoblotting of proteins isolated from analyzed strains: M - low molecular mass marker: 94, 67, 43, 30, 20.1, 14.4 kDa, line 1 - L. johnsonii 142, line 2 - L. johnsonii 151, line 3 - L. rhamnosus LOCK 0900, line 4 - L. casei LOCK 0919, with sera: s1- rabbit polyclonal serum against L. paracasei LOCK 0912, s2 - rabbit polyclonal serum against L. animalis murinus 148, s3 - rabbit polyclonal serum against L. johnsonii 142, s4 - rabbit polyclonal serum against $L$. johnsonii 151, s5 - serum from germ free mouse, s6 - serum from mouse living under pathogen free conditions, s7 - serum from mouse living under conventional conditions, s8-s10 sera from human healthy adults, s11-s13 human umbilical cord blood sera. These images were cut from the same gel, merged and the appropriate scaling was used

analyzed proteins with spectrometric method have been summarized in Table 1 . The highest protein sequence coverage of $L$. johnsonii 142 we observed for spot with molecular mass about $42 \mathrm{kDa}$. This protein has been identified as the phosphoglycerate kinase $(79 \%$ protein sequence coverage), whereas the protein $45 \mathrm{kDa}$ of $L$. johnsonii 151 strain has not been identified. However, we noticed low sequence coverage (39\%) corresponded to hypothetical protein JDM1_1307 from L. plantarum JDM1. Other immunoreactive proteins of L. johnsonii 142 were identified as glyceraldehyde 3-phosphate, dehydrogenase $30 \mathrm{~S}$ ribosomal protein $\mathrm{S} 7$ and surface antigen NLP/P60 with 67,60 and $48 \%$ protein sequence coverage, respectively. Spot with molecular mass of $35 \mathrm{kDa}$ isolated from strain LOCK 0900 was identified as glyceraldehyde 3-phospahte (60\%), however a slightly lower sequence coverage (59\%) was obtained for fructose/tagatose-bisphosphate-aldolase (59\%). The $50 \mathrm{kDa}$ spot of LOCK 0900 was characterized by a low homology with aminopeptidase $C$ (31 \%). Interestingly, the immunoreactive spot with molecular mass around $30 \mathrm{kDa}$ isolated from L. casei LOCK 0919 was identified as fructose/ tagatose-bisphosphate-aldolase $(88 \%$ protein sequence coverage) while for the second analyzed protein $(50 \mathrm{kDa})$ lower score (42 \%) for glucose-6-phosphate isomerase was obtained. 


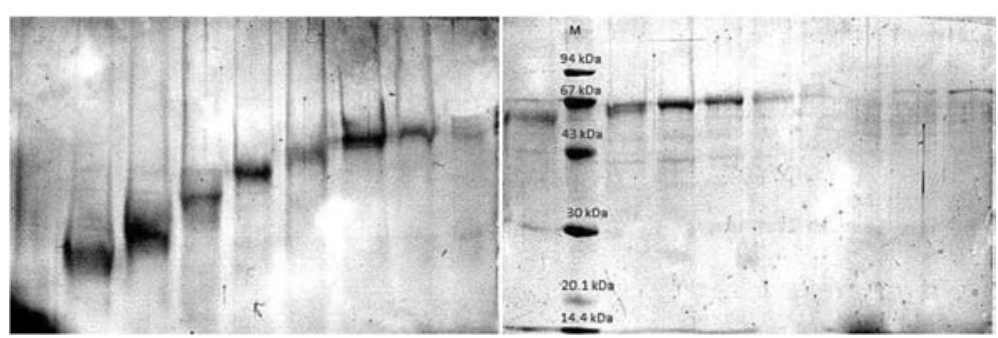

Fig. 3 The SDS-PAGE profile of a separated proteins isolated from Lactobacillus johnsonii 151 in the presence of low molecular mass marker - 94, 67, 43, 30, 20.1, 14.4 kDa by continuous-elution electrophoresis (Prep-Cell apparatus Model 491 Bio-Rad). Samples are electrophoresed through a cylindrical gel. As molecules migrate through the gel matrix, they separate into bands. Individual bands migrate off the bottom of the gel where they pass directly into the patented elution chamber for collection. The resulting liquid fractions $(2 \mathrm{ml})$ were pooled $(5$ fractions), dried and analyzed on SDS-PAGE. Gels were stained with Coomassie Brilliant Blue

\section{Discussion}

The unraveling of the molecular mechanisms underlying the lactobacilli biological effects is an attractive field for investigation. Among the different cellular molecules, proteins might mediate certain interactions, since they would be able to interact directly with host immune system. To date, our knowledge of the identity of proteins responsible for immunomodulatory effect is very limited, although several studies have reported the interaction between lactobacilli proteins and human cells, few have been identified and characterized so far [35-37]. In our studies we focused on identification of potentially immunoreactive/immunogenic proteins of four strains: two isolated from mouse (L. johnsonii 142 and 151) and two isolated from human (L. rhamnosus LOCK 0900 and $L$. casei LOCK 0919) using electrophoretic, immunoblotting and mass spectrometry method. The reactivity of isolated proteins detected by SDS-PAGE and immunoblotting was heterogeneous and varied between different serum samples. The different prevalence of reactions against tested antigens in rabbit, mouse and human sera may indicate significant differences in immune system and commensal cross-talk in these group. The reason could be the way of immunization, as rabbit vaccination differs from a native intestinal stimulation of immunity, moreover rabbit immune response differs markedly from that of mice and human organism. Lactobacilli as food-grade and potentially probiotic organisms with therapeutically purposes should be non-immunogenic reflected in an inability to evoke antibody responses against themselves. However it has been shown that some Lactobacilli and Bifidobacteria strains can stimulate the production of secretory

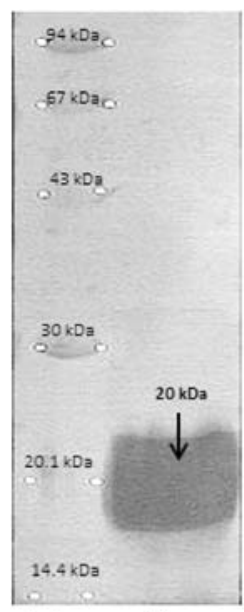

M

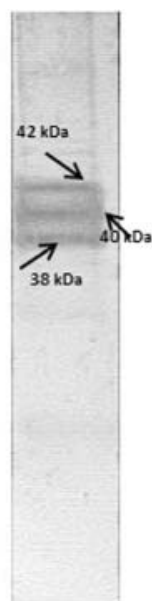

B

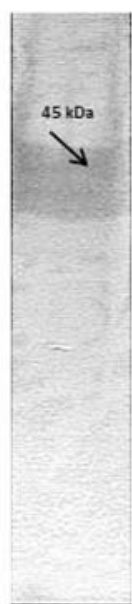

C

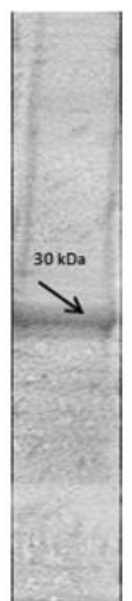

D

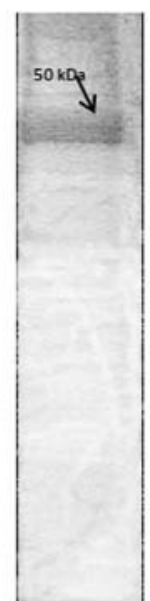

E

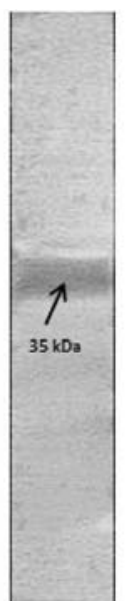

F

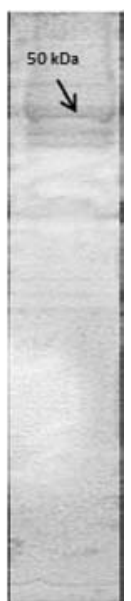

G

Fig. 4 The selected immunoblots of separated proteins: A - immunoreactive protein of L. johnsonii 142 reacting with homologous serum (s3), B - immunoreactive proteins of L. johnsonii 142 reacting with anti-L. paracasei LOCK 0912 (s1), C - immunoreactive protein of L. johnsonii 151 reacting with anti-L. johnsonii 151 (s4), D - immunoreactive proteins of L. rhamnosus LOCK 0900 reacting with anti-L. paracasei LOCK0912 (s1), E - immunoreactive proteins of L. rhamnosus LOCK 0900 reacting with human cord blood sera (s12), F - immunoreactive proteins L. casei LOCK 0919 reacting with mouse CV sera (s6), G - immunoreactive proteins L. casei LOCK 0919 reacting with rabbit anti-L. paracasei LOCK 0912 (s1). These images were taken from different blots, merged and the appropriate scaling was used 
Table 1 Identification of immunoreactive proteins isolated from Lactobacillus strain

\begin{tabular}{|c|c|c|c|c|c|c|}
\hline Strain number & $\begin{array}{l}\text { Estimated molecular mass } \\
\text { of isolated protein }[\mathrm{kDa}]\end{array}$ & Homologous protein name & $\begin{array}{l}\text { Nominal molecular mass of } \\
\text { homologous proteins }[\mathrm{kDa}]\end{array}$ & Origin of homologous protein & Decription & Homology [\%] \\
\hline \multirow[t]{4}{*}{ L. johnsonii 142} & 20 & $\begin{array}{l}\text { 30S ribosomal protein S7 } \\
\text { (gi116495953) }\end{array}$ & 17,912 & Lactobacillus casei ATCC 334 & It is directly linked to the $16 \mathrm{~S} r \mathrm{RNA}$ & 60 \\
\hline & 38 & $\begin{array}{l}\text { Glyceraldehyde 3- } \\
\text { phosphate dehydrogenase } \\
\text { (GAPDH) (gi199597272) }\end{array}$ & 36,929 & Lactobacillus rhamnosus HN001 & $\begin{array}{l}\text { It is involved in the glucose metabolism } \\
\text { and has oxidoreductase activity }\end{array}$ & 67 \\
\hline & 40 & $\begin{array}{l}\text { surface antigen NLP/P60 } \\
\text { (gi } 199598074 \quad \text { ) }\end{array}$ & 40,947 & Lactobacillus rhamnosus GG & Human mucus binding proteinn & 48 \\
\hline & 42 & $\begin{array}{l}\text { phosphoglycerate kinase } \\
\text { (gi } 199597273 \text { ) }\end{array}$ & 42,187 & Lactobacillus rhamnosus HN001 & $\begin{array}{l}\text { It is involved in glycolysis. Transfers a } \\
\text { phosphate group from 1,3- } \\
\text { bisfosfoglicerynianu to ADP creating } \\
\text { 3-phosphoglycerate and ATP. }\end{array}$ & 79 \\
\hline L. johnsonii 151 & 45 & $\begin{array}{l}\text { Hypothetical protein } \\
\text { JDM1_1307 (gi } \\
254556474 \text { ) }\end{array}$ & 44,729 & Lactobacillus plantarum JDM1 & Function unknown & 39 \\
\hline \multirow[t]{3}{*}{$\begin{array}{l}\text { L. rhamnosus } \\
\text { LOCK } 0900\end{array}$} & 35 & $\begin{array}{l}\text { Glyceraldehyde 3- } \\
\text { phosphate dehydrogenase } \\
\text { (GAPDH) (gi116494473) }\end{array}$ & 36,912 & Lactobacillus casei ATCC 334 & $\begin{array}{l}\text { It is involved in the glucose metabolism } \\
\text { and has oxidoreductase activity }\end{array}$ & 60 \\
\hline & & $\begin{array}{l}\text { Fructose/tagatose- } \\
\text { bisphosphate-aldolase } \\
\text { (gi229551479 ) }\end{array}$ & 36,360 & $\begin{array}{l}\text { Lactobacillus rhamnosus LMS2- } \\
1\end{array}$ & $\begin{array}{l}\text { It is involved in the metabolism of } \\
\text { carbohydrates. It also participates } \\
\text { in the binding of zinc ions, and } \\
\text { its activity is stimulated by some } \\
\text { bivalent ions }\end{array}$ & 59 \\
\hline & 50 & $\begin{array}{l}\text { Aminopeptidase C } \\
\text { (gi258509341 ) }\end{array}$ & 50,737 & Lactobacillus rhamnosus GG & It is involved in proteolysis & 31 \\
\hline \multirow[t]{2}{*}{$\begin{array}{l}\text { L. casei LOCK } \\
0919\end{array}$} & 30 & $\begin{array}{l}\text { Fructose/Tagatose- } \\
\text { bisphosphate-aldolase } \\
\text { (gi116493996 ) }\end{array}$ & 31,640 & Lactobacillus casei ATCC 334 & $\begin{array}{l}\text { It is involved in the metabolism of } \\
\text { carbohydrates. It also participates } \\
\text { in the binding of zinc ions, and } \\
\text { its activity is stimulated by some } \\
\text { bivalent ions }\end{array}$ & 88 \\
\hline & 50 & $\begin{array}{l}\text { Glucose-6-phosphate } \\
\text { isomerase (gi116494625 ) }\end{array}$ & 49,292 & Lactobacillus casei ATCC 334 & $\begin{array}{l}\text { Catalyze the reaction: transformation } \\
\text { of D-glucose-6-phosphate into D- } \\
\text { fructose-6-phosphate }\end{array}$ & 42 \\
\hline
\end{tabular}


antibodies such as IgA and IgG. Maassen et a. described that orally administered individual Lactobacillus strains are able to differentially affect IgG1 versus IgG2a antibody, depending on bacteria growth phase [38]. Prangli et al. found IgG antibodies against common lactobacilli cytoplasmic proteins GroEl, enolase, transcription factor EF-Ts and EF-Tu in children with type 1 diabetes and coeliac disease [39]. In our study we also indicate immunoreactive proteins which are recognized by rabbit/mouse and human immune system and elicit an antibodies. The proteins with the highest immunoreactivity were isolated, purified and sequenced, in particular the fractions were identified as phosphoglycerate kinase, $30 \mathrm{~S}$ ribosomal protein, surface antigen NLP/P60 (L. johnsonii 142), glyceraldehyde 3phosphate dehydrogenase (L. johnosnii 142, L. rhamnosus LOCK 0900), hypothetic protein JDM1_1307 (L. johnosnii 151), fructose/tagatose-bisphosphate-aldolase (L. casei LOCK 0919 and L. rhamnosus LOCK 0900) and glucose6-phosphate isomerase (L. casei LOCK 0919) and aminopeptidase C (L. rhamnosus LOCK 0900). This protein are well-known as cytosolic metabolic enzymes or translation protein and not as a surface proteins. However, over the past decade, it has become clear that many proteins have one or more unique functions over-and-above the principal biological action of the specific protein. This phenomenon is now known as protein moonlighting. The mechanism of how bacterial moonlighting proteins translocate to the cell exterior has remained unknown. They can be released from dead or damaged cells and then bind to neighboring cells, or they can be secreted onto the cell surface by an as-yetundescribed mechanism [40]. Most of multifunctional proteins described in literature are virulence factors of Grampositive pathogens. Homologs have been also identified either cell-surface-associated and/or in extracellular space of commensal bacteria including lactobacilli. Their number and moonlighting functions have significantly increased during the last five years. The identified immunoreactive glycolytic enzymes glyceraldehyde-3-phosphate dehydrogenase, phosphoglycerate kinase, glucose-6-phosphate isomerase and $30 \mathrm{~S}$ ribosomal protein are among the most common of the commensal bacterial moonlighting proteins [41]. Lactic acid bacteria display on the cell surface cytosolic proteins that recognize yeast mannan. The glyceraldehyde 3-phosphate dehydrogenase (GAPDH) is involved in glucose metabolism, catalyzing the metabolism of glucose to release carbon as an energy source, however the other study shown that play important role in adhesion phenomena, or as immunomodulatory factor and recognizes human A and B blood group antigens [42, 43]. Studies have shown that commensal Lactobacillus crispatus and several other species of the acidophilus group of Lactobacillus have GAPDH as major constituents of their extracellular proteome at neutral $\mathrm{pHs}$ and that they are easily released from the cell surface into incubation buffer $[44,45]$. The catalytic site in the GAPDH protein was suggested to be involved in the binding to colonic mucin since the binding was inhibited by NAD [46]. Extracellular GAPDH of $L$. plantarum also binds fibronectin [47]. GAPDH and phosphoglycerate kinase were found to be secreted to culture media by $L$. rhamnosus GG [48]. In our work we indicated that GAPDH is at least one of immunogenic protein of Lactobacillus johnsonii 142 and immunoreactive protein of $L$. rhamnosus LOCK 0900 and suggested the importance in cross-talk between bacteria and their host. Previously it was shown that GAPDH of S. agalactiae is an immunomodulatory protein and that recombinant GAPDH activates $\mathrm{T}$ and B cells [49]. The GAPDH of S. pneumoniae was reported to be antigenic in humans as well as to elicit protective immune responses in the mouse [50].

A part from immunogenic GAPDH, the main immunoreactive protein $42 \mathrm{kDa}$ of $L$. johnsonii 142 was identified as phosphoglycerate kinase (PGK). This enzyme catalyses the reversible phosphoryl transfer between 1,3-bisphosphoglycerate and ADP to form 3-phosphoglycerate and ATP, and plays a crucial role in the Embden-MeyerhofParnas pathway of glycolysis and in gluconeogenesis. This important role is reflected by the enzyme structure that has been highly conserved throughout evolution [51]. It has been shown that PGK isolated from $L$. delbrueckii subsp. lactis NCC88 plays a crucial function in regenerating ATP, however in not allosteric enzyme suggesting that is not one of the key enzymes of the energy metabolism regulation of $L$. delbrueckii subsp. lactis [52]. In addition, PGK has been recognized as protective antigen against various serotype of Streptococcus agalactiae and the hyperimmune sera against phosphoglycerate kinase protect neonatal animals from S. agalactiae infection [53]. We identified the most immunoreactive $30 \mathrm{kDa}$ protein of Lactobacillus paracasei LOCK 0919 (human origin) as fructose/tagatose-1,6-bisphosphate-aldolase which is the fourth enzyme in glycolysis and catalyses the reversible cleavage of fructose-1, 6-bisphosphate into dihydroxyacetone phosphate and glyceraldehyde 3-phosphate. Aldolase was found in mutanolysin extract of S. pneumoniae. Antibodies against aldolase protected against respiratory challenge with S. pneumoniae [50]. This study demonstrates for the first time that GAPDH, PGK fructose/tagatosebisphosphate-aldolase, $30 \mathrm{~S}$ ribosomal protein, glucose-6phosphate isomerase and aminopeptidase $C$ from Grampositive commensal strain not pathogen are able to induce the immune response and elicited antibodies.

All studied nonimmune human sera, not only of adult blood donors, but also from umbilical cord sera, contain antibodies recognizing Lactobacillus casei LOCK 0919 derived main protein of $90 \mathrm{kDa}$. The presence of anti$90 \mathrm{kDa}$ protein antibodies in human sera is unclear and our studies are initiated to solve the question of the biological role of such antibodies. 
Interestingly, in our previous study we have shown that L. johnsonii 142 isolated from mouse with inflammatory bowel disease (IBD) produced polysaccharide with different structure than L. johnsonii 151 isolated from healthy mouse, also reflected in their immunoreactivity $[33,34]$. The strains varied also considerably in reactivity of their protein. This could suggest the relation of bacterial antigens synthesized by bacteria colonizing the gut with ongoing inflammatory process, especially surface antigens. The question arises whether resident strains of IBD mice could start the regulation of several proteins or production of surface antigens with specific motifs in their structure, which are absent in antigens of bacteria from the normal gut flora. This also may suggest that the antigens of lactobacilli may have an effect on host responses related to the inflammatory process in IBD.

Comparison of the results showed that there was a great diversity in the immunoreactive proteins amongst the lactobacillus strains, however there were some similarities and consistencies amongst strains both within the species and across the species. In particular it may be of relevance that the presence of GAPDH in mouse and human origin strains were detected as one of the reactive proteins with various sera. However, all identified proteins are common immunogenic proteins that are present in several microorganisms and could well contribute to the known immunomodulatory effect of lactobacilli.

\section{Conclusions}

During the last ten years, the number of applications developed or suggested for Lactobacillus has gradually increased [54]. One of the fields currently studied is the development of vaccine based on lactobacilli. It has been already shown that Lactobacillus increase the immunogenicity of orally administrated vaccines such as rotavirus [55], polio [56], cholera [57] or influenza [58]. Recently, extensively analyzed is the construction of Slayer protein for use in immunization in man or animals [59-61]. The identification in our study of immunoreactive proteins opens the possibility to use them also as carries of antigens or other medically important molecules, possibly in combinations with immunostimulatory or adhesive molecules.

\section{Methods}

\section{Microorganisms and growth conditions}

The strain of Lactobacillus johnsonii 151 was isolated from the intestinal tract of healthy mice housed under SPF conditions, whereas Lactobacillus johnsonii 142 was isolated from the intestinal tract of mice with experimentally induced inflammatory bowel disease. The species identification was performed using either PCR with primers for 16S-23S rRNA or rep-PCR using GTG5 primers [33, 34]. Lactobacillus rhamnosus LOCK 0900 (formerly Lactobacillus casei LOCK900 [62]; patent no. 209988) was isolated from feces of a healthy 26-year-old woman, whereas Lactobacillus casei LOCK 0919 (formerly Lactobacillus paracasei LOCK919 [63]; patent no. 209986), was originally isolated from a fecal sample collected from healthy 5-year-old boy. Both strains were obtained from the Pure Culture Collection of the Technical University, Lódz, Poland. The species of the Lactobacillus genus were identified based on the sequences of genomic markers, such as $16 \mathrm{~S}$ rRNA, rpoA, and pheS genes [64].

The strains were stored at $-75{ }^{\circ} \mathrm{C}$ in MRS broth (Difco) supplemented with $20 \%$ glycerol, and were subcultured twice in MRS broth (Biocorp) under anaerobic conditions at $37^{\circ} \mathrm{C}$ before use. The growth of the organism was carried out at $37^{\circ} \mathrm{C}$ for $48 \mathrm{~h}$.

Other lactobacilli strains: L. animalis murinus 148 (mouse origin) and L. casei LOCK0912 (human origin) were used for the preparation of rabbit antisera and were cultivated in the same conditions.

\section{Protein isolation}

Bacterial strains were cultured on MRS broth (Biocorp) for $48 \mathrm{~h}$ at $37{ }^{\circ} \mathrm{C}$ and centrifuged $\left(6000 \mathrm{~g}, 4{ }^{\circ} \mathrm{C}, 20 \mathrm{~min}\right)$ than suspended directly in the buffer for electrophoresis according to Heilmann et al. [65]. Briefly, the cell pellet was resuspended in 1 volume of buffer: $0.5 \mathrm{M}$ Tris- $\mathrm{HCl}$ $(\mathrm{pH}=6,8) / \mathrm{SDS}(0,08 \% \mathrm{w} / \mathrm{v}) /$ glycerol $(20 \% \mathrm{v} / \mathrm{v}) / 1 \mathrm{mM}$ $\beta$-mercaptoethanol $(\mathrm{v} / \mathrm{v})$ and boiled for $5 \mathrm{~min}$. After centrifugation, proteins were precipitated from the resulting supernatant using 3 volumes of cold $95 \%$ ethanol (POCh). After overnight incubation at $4{ }^{\circ} \mathrm{C}$, the precipitated proteins were centrifuged $(12000 \mathrm{rpm})$ and dissolved in water. Protein concentration was analyzed using the Lowry's method [66].

In experiments with Lactobacillus rhamnosus LOCK900 which is characterized by high amount of slime production [67], before protein isolation procedure, the polysaccharide slime which was loosely attached to bacterial cells was removed mechanically by several centrifugation at $14500 \mathrm{~g}$.

\section{SDS-PAGE and immunoblotting}

Equal amounts of proteins samples $(10 \mu \mathrm{g})$ were analyzed on SDS-PAGE using 5 to $12.5 \%$ gels according to Laemmli [68]. Electrophoretic separation were carried out at $100 \mathrm{~V}$, using Tris-Glycine-SDS as running buffer. After electrophoresis, gels were stained with Coomassie Brilliant Blue (Serva) or soaked in transfer buffer (10 mM Tris- $\mathrm{HCl}, 150 \mathrm{mM}$ glycine, $20 \%$ methanol, $\mathrm{pH}$ 8.3) for $30 \mathrm{~min}$. and transferred to a polyvinylidene difluoride membrane (Millipore) for immunoblotting (for $1 \mathrm{~h}$ at $100 \mathrm{~V}$ ). Then the membranes were blocked in 
phosphate buffered saline (PBS) containing $1 \%$ of bovine serum albumin (BSA, KPL) for $1 \mathrm{~h}$. Afterwards, the membranes were washed three times with PBS containing $0.25 \%$ Tween 20 (Sigma-Aldrich), PBS-T (Institute of Immunology and Experimental Therapy, PAN), and incubated in a selected sera in $1 \%$ BSA for $2 \mathrm{~h}$ at $37{ }^{\circ} \mathrm{C}$. We tested different dilutions of sera but the most effective was: for rabbit sera 1:10000, mouse sera 1:1000 and for human sera 1:3000 (reproducible results, without the Hook effect). Next, the membranes were washed three times with PBS-T. After washing, the membranes were incubated for $1 \mathrm{~h}$ in alkaline phosphatase-conjugated goat-anti-rabbit/mouse/human IgG antibodies (Sigma) diluted $1: 5000$. Finally, the membranes were washed as six times with PBS-T, and visualized with solution containing nitro blue tetrazolium (NBT, Roth), 5-bromo-4chloro-3-indolyl phosphate (BCIP, Roth), and $\mathrm{MgCl}_{2}$ (POCh) for $5 \mathrm{~s}$. Image acquisition (exposure time 14 min) was performed using VersaDoc Imaging System (Bio-Rad).

\section{Protein identification}

After Western blot analysis, the immunoreactive proteins were separated and purified by preparative electrophoresis in denaturing condition (SDS-PAGE) using Prep-Cell apparatus (Model 491 Bio-Rad). Bands of interest were cut out and digested by trypsin (Roche) to obtain a mixture of peptides and analyzed by liquid chromatography (LC), where the mass fragments were measured using mass spectrometer LC-MS/MS Orbitrap (Thermo). Peptides were first trapped and desalted on the enrichment column (Zorbax 300SB-C18, $0.3 \times$ $5 \mathrm{~mm}$, Agilent) for $5 \mathrm{~min}$ (solvent: $2.5 \%$ acetonitrile/ $0.5 \%$ formic acid), then separated on a Zorbax 300SBC18, $75 \mu \mathrm{m} \times 150 \mathrm{~mm}$ column (Agilent), using a linear gradient from 10 to $32 \%$ B (solvent A: $5 \%$ acetonitrile in water, solvent $\mathrm{B}$ : acetonitrile, both with $0.1 \%$ formic acid). Ions of interest were data-dependently subjected to MS/MS, according to the expected charge state distribution of peptide ions. Proteins were identified by comparative analysis of peptides masses (NCBInr, UniProt, Bethesda, USA), using MS/MS ion search of the Mascot search engine (Matrix Science, London, UK, http:// www.matrixscience.com/) and statistical analysis. Only peptide matches with a score of 1000 or above were accepted. Immunoreactive properties of separated proteins were re-tested using immunoblotting.

\section{Serum samples}

Thirteen sera were used: four polyclonal rabbit sera, three mouse sera and six human sera (three of healthy adult volunteers and three from umbilical cord blood). Serum was obtained from rabbits immunized with bacterial mass of L. paracsei LOCK 0912 (s1), L. animalis murinus 148 (s2), L. johnsonii 142 (s3) and L. johnsonii 151 (s4) as described before [33]. Briefly, rabbits (5-6 months old) were immunized twice a week with a dried cell mass suspended in PBS. After the first subcutaneous injection with $100 \mu \mathrm{g} / \mathrm{ml}$, the succeeding doubly increasing amounts (200 to $6400 \mu \mathrm{g} / \mathrm{ml}$ ) were injected intravenously. After the last injection rabbits were bled, the separated antisera were decomplemented $\left(56{ }^{\circ} \mathrm{C}, 30 \mathrm{~min}\right)$ and stored at $-20{ }^{\circ} \mathrm{C}$. Preimmune serum was used as a control. The experiments were approved by the $1^{\text {st }}$ Local Committee for Experiments with the Use of Laboratory Animals, Wroclaw, Poland (number 12/2012). Serum was obtained from germ free mouse (GF, s5), mouse kept under specific-pathogen-free conditions (SPF, s6) and form mouse kept under conventional conditions $(\mathrm{CV}, \mathrm{s} 7)$. Germ free BALB/c mice were kept under sterile conditions in Trexler-type plastic isolators, exposed to 12:12-h light-dark cycles and supplied with autoclaved tap water and $50 \mathrm{kGy}$ irradiated sterile pellet diet Altromin 1410 (Altromin, Lage, Germany) ad libitum. Fecal samples were weekly controlled for the presence of aerobic and anaerobic bacteria, molds and yeast by standard microbiological methodology. Conventional BALB/c mice were kept in IVC cages (Tecniplast, Italy), exposed to 12:12-h lightdark cycles and fed with the same sterile diet as GF counterparts. Animal experiments were approved by the committee for protection and use of experimental animals of the Institute of Microbiology. v.v.i., Academy of Sciences of the Czech Republic. Human adults sera were obtained from healthy volunteers (s8-s10) and human umbilical cord sera from healthy women (s11-s13) were obtained from the Obstetric Clinic of the Medical University of Wroclaw. Samples were obtained with patients' written informed consent. The use of umbilical cord sera samples in this study was approved by the Medical Ethics Committee of the Medical University of Wroclaw (number KB-8822012) and was conducted in accordance with the Helsinki Declaration of 1975.

\section{Abbreviations \\ BCIP: bromo-4-chloro-3-indolyl phosphate; BSA: bovine serum albumin; CV: convetional; EF-Tu: elongation factor Tu; GAPDH: glyceraldehyde 3- phosphate dehydrogenase; GF: germ free; IBD: inflammatory bowel disease; L.: Lactobacillus; LC: liquid chromatography; MucBPs: putative mucus binding proteins; NBT: nitro blue tetrazolium; PBS: phosphate buffered saline; PGK: phosphoglycerate kinase; s: serum; SDS-PAGE: sodium dodecyl sulfate - polyacrylamide gel electrophoresis; SPF: specific pathogen free.}

\section{Competing interests}

The authors declare that they have no competing interests.

\section{Authors' contributions}

SG designed, coordinated and conceived of the study, performed the protein identification and drafted the manuscript, BB carried out the immunoassays and helped to draft the manuscript, protein isolation and purification, EB prepared the anti-rabbit and human sera, MS prepared the lactobacilli strains and helped to draft the manuscript, DG prepared the mouse sera, HK contributed reagents/materials and help to draft the 
manuscript, AG was a supervisor and helped to draft the manuscript. All authors read and approved the final manuscript.

\section{Acknowledgment}

Publication supported by Wroclaw Centre of Biotechnology, programme The Leading National Research Centre (KNOW) for years 2014-2018". This work was supported by grants CZ.3.22/2.1.00/09.01574 and CZ.3.22/2.1.00/ 13.03892. co-funded by the European Regional Development Fund under Operational Programme Cross-border Cooperation Czech RepublicRepublic of Poland 2007-2013, under the European Territorial Cooperation Objective.

\section{Author details}

'Department of Medical Microbiology, Ludwik Hirszfeld Institute of Immunology and Experimental Therapy of the Polish Academy of Sciences, Wroclaw, Poland. ${ }^{2}$ Department of Animal Products Technology and Quality Management, Wroclaw University of Environmental and Life Sciences, Faculty of Food Science, Wroclaw, Poland. Institute of Microbiology, Laboratory of Gnotobiology, Academy of Sciences of the Czech Republic v. v. i., 54922 Novy Hradek, Czech Republic.

Received: 12 March 2015 Accepted: 22 January 2016

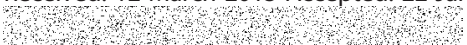

\section{References}

1. Beganovi J, Frece J, Kos B, Pavunc AL, Habjani K, Su kovi J. Functionality of the S-layer protein from the probiotic strain Lactobacillus helveticus M92. Antonie Van Leeuwenhoek. 2011:100:43-53.

2. Górska S, Jarz b A, Gamian A. Probiotic bacteria in the human gastrointestinal tract as a factor stimulating the immune system. Postepy Hig Med Dosw. 2009;63:653-67.

3. Martínez MG, Acosta MP, Candurra NA, Ruzal SM. S-layer proteins of Lactobacillus acidophilus inhibits JUNV infection. Biochem Biophys Res Commun. 2012:422:590-95.

4. Matija i BB, Narat M, Peternel MZ, Rogelj I. Ability of Lactobacillus gasseri KZ to inhibit Escherichia coli adhesion in vitro on Caco-2 cells and ex vivo on pigs' jejunal tissue. Int J Food Microbiol. 2006;107:92-6.

5. Yan F, Cao H, Cover TL, Whitehead R, Washington MK, Polk DB. Soluble proteins produced by probiotic bacteria regulate intestinal epithelial cell survival and growth. Gastroenterol. 2007;132:562-75.

6. Taverniti V, Guglielmetti S. The immunomodulatory properties of probiotic microorganisms beyond their viability (ghost probiotics: proposal of paraprobiotic concept). Genes Nutr. 2011:6:261-74.

7. Båth $\mathrm{K}$, Roos $\mathrm{S}$, Wall $\mathrm{T}$, Jonsson $\mathrm{H}$. The cell surface of Lactobacillus reuteri ATCC 55730 highlighted by identification of 126 extracellular proteins from the genome sequence. FEMS Microbiol Lett. 2008;253:75-82.

8. Driessen AJ, Nouwen N. Protein translocation across the bacterial cytoplasmic membrane. Annu Rev Biochem. 2008;77:643-67.

9. Sánchez B, Chaignepain S, Schmitter JM, Urdac MC. A method for the identification of proteins secreted by lactic acid bacteria grown in complex media. FEMS Microbiol Lett. 2009:295:226-9.

10. Kleerebezem M, Hols P, Bernard E, Rolain T, Zhou M, Siezen RJ, et al. The extracellular biology of the lactobacilli. FEMS Microbiol Rev. 2010:34:199-230

11. Remus DM, Bongers RS, Meijerink M, Fusetti F, Poolman B, de Vos P, et al. Impact of Lactobacillus plantarum sortase on target protein sorting, gastrointestinal persistence, and host immune response modulation. J Bacteriol. 2013;195:502-9.

12. Chen X, Chen Y, Li X, Chen N, Fang W. Characterization of surface layer proteins in Lactobacillus crispatus isolate ZJ001. J Microbiol Biotechnol. 2009;19:1176-83

13. Khaleghi M, Kermanshahi RK. Effect of environmental stresses on s-layer production in Lactobacillus acidophilus ATCC 4356. In: Petre M, editor. Advances in Applied Biotechnology. 2012. ISBN: 978-953-307-820-5.

14. Rojas M, Ascencio F, Conway PL. Purification and characterization of a surface protein from Lactobacillus fermentum 104R that binds to porcine small intestinal mucus and gastric mucin. Appl Environ Microbiol. 2002;68:2330-6.

15. Avall-Jaaskelainen S, Palva A. Lactobacillus surface layers and their applications. FEMS Microbiol Rev. 2005;29:511-29.
16. Bernet MF, Brassart D, Neeser JR, Servin AL. Lactobacillus acidophilus LA1 binds to cultured human intestinal cell lines and inhibits cell attachment and cell invasion by enterovirulent bacteria. Gut. 1994;35:483-9.

17. Candela M, Perna F, Carnevali P, Vitali B, Ciati R, Gionchetti P, et al. Interaction of probiotic Lactobacillus and Bifidobacterium strains with human intestinal epithelial cells: adhesion properties, competition against enteropathogens and modulation of IL-8 production. Int J Food Microbiol. 2008;125:286-92

18. Carasi P, Trejo FM, Pérez PF, De Antoni GL, De los Angeles Serradell M. Surface proteins from Lactobacillus kefir antagonize in vitro cytotoxic effect of Clostridium difficile toxins. Anaerobe. 2012;18:135-42.

19. Coconnier MH, Bernet MF, Kernéis S, Chauvière G, Fourniat J, Servin AL. Inhibition of adhesion of enteroinvasive pathogens to human intestinal Caco-2 cells by Lactobacillus acidophilus strain LB decreases bacterial invasion. FEMS Microbiol Lett. 1993;1 10:299-305.

20. Granato D, Bergonzelli GE, Pridmore RD, Marvin L, Rouvet M, CorthésyTheulaz IE. Cell surface-associated elongation factor Tu mediates the attachment of Lactobacillus johnsonii NCC533 (La1) to human intestinal cells and mucins. Infect Immun. 2004:72:2160-69.

21. Reunanen J, von Ossowskia I, Hendrick APA, Palva A, de Vos WM. Characterization of the SpaCBA Pilus Fibers in the Probiotic Lactobacillus rhamnosus GG. Appl Environ Microbiol. 2012;78:2337-44.

22. Neville BA, Forde BM, Claesson MJ, Darby T, Coghlan A, Nally K, et al. Characterization of pro-inflammatory flagellin proteins produced by Lactobacillus ruminis and related motile lactobacilli. PloS. 2012;7:40592.

23. Sanchez B, Urdaci MC, Margolles A. Extracellular proteins secreted by probiotic bacteria as mediators of effects that promote mucosa-bacteria interactions. Microbiology. 2010;156:3232-42.

24. Buck BL, Altermann E, Svingerud T, Klaenhammer TR. Functional analysis of putative adhesion factors in Lactobacillus acidophilus NCFM. Appl Environ Microbiol. 2005;71:8344-51.

25. Boekhorst J, Helmer Q, Kleerebezem M, Siezen RJ. Comparative analysis of proteins with a mucus-binding domain found exclusively in lactic acid bacteria. Microbiology. 2006;152:273-80.

26. Van Tassell ML, Miller MJ. Lactobacillus adhesion to mucus. Nutrients. 2011:3:613-36

27. Macías-Rodríquez ME, Zagorec M, Ascencio F, Vázquez-Juárez R, Rojas M. Lactobacillus fermentum BCS87 expresses mucus- and mucin-binding proteins on the cell surface. J Appl Microbiol. 2009;107:1866-74.

28. von Ossowski I, Satokari R, Reunanen J, Lebeer S, De Keersmaecker SCJ, Vanderleyden J, et al. Functional characterization of a mucus-specific LPXTG surface adhesin from probiotic Lactobacillus rhamnosus GG. Appl Environ Microbiol. 2011;77:4465-72

29. Munoz-Provencio D, Rodríguez-Díaz J, Collado MC, Langella P, BermúdezHumarán LG, Monedero V. Functional analysis of the Lactobacillus casei BL23 sortases. Appl Environ Microbiol. 2012;78:8684-93.

30. Lebeer S, Vanderleyden J, De Keersmaecker SC. Genes and molecules of lactobacilli supporting probiotic action. Microbiol Mol Biol Rev. 2008;72:728-64.

31. Lebeer S, Vanderleyden J, De Keersmaecker SC. Host interactions of probiotic bacterial surface molecules: comparison with commensals and pathogens. Nat Rev Microbial. 2010;8:171-84.

32. Sengupta R, Altermann E, Anderson RC, McNabb WC, Moughan PJ, Roy NC. The role of cell surface architecture of lactobacilli in host-microbe interactions in the gastrointestinal tract. Mediators Inflamm. 2013; doi:10. 1155/2013/237921.

33. Górska S, Jachymek W, Rybka J, Strus M, Heczko PB, Gamian A. Structural and immunochemical studies of neutral exopolysaccharide produced by Lactobacillus johnsonii 142. Carbohydr Res. 2010;345:108-14.

34. Górska-Fr czek S, Sandström C, Kenne L, Pa ciak M, Brzozowska E, Strus M, et al. The structure and immunoreactivity of exopolysaccharide isolated from Lactobacillus johnsonii strain 151. Carbohydr Res. 2013;378:148-53.

35. Konstantinov SR, Smidt H, de Vos WM, Bruijns SCM, Singh SK, Valence F, et al. S layer protein A of Lactobacillus acidophilus NCFM regulates immature dendritic cell and T cell functions. Proc Natl Acad Sci U S A. 2008;105:19474-79.

36. Bergonzellii GE, Granato D, Pridimore RD, Marvin-Guy LF, Donnicola D, Corthesy-Theulaz IE. GroEL of Lactobacillus johnsonii La1 (NCC 533) is cell surface associated: potential role in interactions with the host and the gastric pathogen Helicobacter pylori. Infect Immun. 2006;74:425-34.

37. Choi CH, Kim TI, Lee SK, Yang KM, Kim WH. Effect of Lactobacillus GG and conditioned media on IL-1 beta-induced IL-8 production in Caco-2 cells. Scand J Gastroenterol. 2008;43:938-47. 
38. Maassen CBM, Boersma WJA, van Holten-Neelen C, Claassen E, Laman JD. Growth phase of orally administered Lactobacillus strains differentially affects lgG1/lgG2a ratio for soluble antigens: implications for vaccine development. Vaccine. 2003;21:2751-57.

39. Prangli AL, Utt M, Talja I, Sepp E, Mikelsaar M, Rajasalu T, et al. Antigenic proteins of Lactobacillus acidophilus that are recognised by serum lgG antibodies in children with type 1 diabetes and coeliac disease. Pediatr Allergy Immunol. 2010;21:772-79.

40. Henderson B, Martin A. Bacterial virulence in the moonlight: multitasking bacterial moonlighting proteins are virulence determinants in infectious disease. Infect Immun. 2011;79:3476-91.

41. Katakura Y, Sano R, Hashimoto T, Ninomiya K, Shioya S. Lactic acid bacteria display on the cell surface cytosolic proteins that recognize yeast mannan. Appl Microbiol Biotechnol. 2010;86:319-26.

42. Mangiapane E, Lamberti C, Pessione A, Ceruti P, Novelli F, Galano E, et al. An integrated proteomic and physiological approach to understand the adhesion mechanism of the probiotic Lactobacillus reuteri Lb2 BM DSM 16143. JIOMICS. 2013;3:145-56.

43. Kinoshita $\mathrm{H}$, Wakahara N, Watanabe M, Kawasaki T, Matsuo H, Kawai $Y$, et al. Cell surface glyceraldehyde-3-phosphate dehydrogenase (GAPDH) of Lactobacillus plantarum LA 318 recognizes human A and B blood group antigens. Res Microbiol. 2008;159:685-91.

44. Antikainen J, Kuparinen V, Lahteenmaki K, Korhonen TK.pH-dependent association of enolase and glyceraldehyde-3-phosphate dehydrogenase of Lactobacillus crispatus with the cell wall and lipoteichoic acids. J Bacteriol. 2007;189:4539-4543.

45. Hurmalainen V, Edelman S, Antikainen J, Baumann M, Lahteenmaki K, Korhonen TK. Extracellular proteins of Lactobacillus crispatus enhance activation of human plasminogen. Microbiology. 2007;153:1112-22.

46. Kinoshita H, Uchida H, Kawai Y, Kawasaki T, Wakahara N, Matuo H, et al. Cell surface Lactobacillus plantarum LA 318 glyceraldehyde-3-phosphate dehydrogenase (GAPDH) adheres to human colonic mucin. J Appl Microbiol. 2008;104:1667-74.

47. Sánchez B, Schmitter JM, Urdaci MC. Identification of novel proteins secreted by Lactobacillus plantarum that bind to mucin and fibronectin. J Mol Microbiol Biotechnol. 2009;17:158-62.

48. Sanchez B, Schmitter JM, Urdaci MC. Identification of novel proteins secreted by Lactobacillus rhamnosus GG grown in de mann rogosa sharpe broth. Lett Apl Microbiol. 2009;48:618-622.

49. Madureira P, Baptista M, Vieira M, Magalhães V, Camelo A, Oliveira L, et al. Streptococcus agalactiae GAPDH is a virulence-associated immunomodulatory protein. J Immunol. 2007;178:1379-87.

50. Ling E, Feldman G, Portnoi M, Dagan R, Overweg K, Mulholland F, et al. Glycolytic enzymes associated with the cell surface of Streptococcus pneumoniae are antigenic in humans and elicit protective immune responses in the mouse. Clin Exp Immunol. 2004;138:290-98.

51. Mori N, Singer-Sam J, Riggs AD. Evolutionary conservation of the substratebinding cleft of phosphoglycerate kinases. FEBS Lett. 1986;204:313-17.

52. Bourniquel AA, Mollet B. Purification and characterization of the 3-phosphoglycerate kinase from the thermophile Lactobacillus delbrueckii subsp. lactis. Int Dairy J. 2002;12:723-28.

53. Hughes MJG, Moore JC, Lane JD, Wilson R, Pribul PK, Younes ZN, et al. Identification of major outer surface proteins of Streptococcus agalactiae. Infect Immunol. 2002;70:1254-59.

54. Nagpal R, Kumar A, Kumar M, Behare PV, Jain S, Yadav H. Probiotics, their health benefits and applications for developing healthier foods: a review. FEMS Microbiol Lett. 2012;334:1-15.

55. Isolauri E, Joensuu J, Suomalainen H, Luomala M, Vesikari T. Improved immunogenicity of oral $\mathrm{D} \times \mathrm{RRV}$ reassortant rotavirus vaccine by Lactobacillus casei GG. Vaccine. 1995;13:310-12.

56. de Vrese M, Rautenberg P, Laue C, Koopmans M, Herremans T, Schrezenmeir J. Probiotic bacteria stimulate virus-specific neutralizing antibodies following a booster polio vaccination. Eur J Nutr. 2005:44:406-13.

57. Paineau D, Carcano D, Leyer G, Darquy S, Alyanakian MA, Simoneau G, et al. Effects of seven potential probiotic strains on specific immune responses in healthy adults: a double-blind, randomized, controlled trial. FEMS Immunol Med Microbiol. 2008;53:107-13.

58. Kobayashi N, Saito T, Uematsu T, Kishi K, Toba M, Kohda N, et al. Oral administration of heat-killed Lactobacillus pentosus strain b240 augments protection against influenza virus infection in mice. Int Immunopharmacol. 2011;11:199-203.
59. Khang YH, Park HY, Jeong YS, Kim JA, Kim YH. Recombinant S-layer proteins of Lactobacillus brevis mediating antibody adhesion to calf intestine alleviated neonatal diarrhea syndrome. J Microbiol Biotechnol. 2009:19:511-19.

60. Heikki Vilen H, Hynönen U, Badelt-Lichtblau H, Ilk N, Jääskeläinen P, Torkkeli $\mathrm{M}$, et al. Surface location of individual residues of SIpA provides insight into the Lactobacillus brevis S-Layer. J Bacteriol. 2009;191:3339-49.

61. Åvall-Jääskeläinen S, Kylä-Nikkilä K, Kahala M, Miikkulainen-Lahti T, Palva A. Surface display of foreign epitopes on the Lactobacillus brevis S-layer. Appl Environ Microbiol. 2002;68:5943-51.

62. Aleksandrzak-Piekarczyk T, Koryszewska-Bagińska A, Bardowski J. Genome sequence of the probiotic strain Lactobacillus rhamnosus (formerly Lactobacillus casei) LOCK900. Genome Announc. 2013. doi:10.1128/genomeA.00640-13.

63. Aleksandrzak-Piekarczyk T, Koryszewska-Bagińska A, Bardowski J. Complete genome sequence of the probiotic strain Lactobacillus casei (formerly Lactobacillus paracasei) LOCK919. Genome Announc. 2013. doi:10.1128/genomeA.00758-13.

64. Naser SM, Dawyndt P, Hoste B, Gevers D, Vandemeulebroecke K, Cleenwerck I, et al. Identification of lactobacilli by pheS and rpoA gene sequence analyses. Int J Syst Evol Microbiol. 2007;57:2777-89.

65. Heilmann C, Gerke C, Perdreau-Remington F, Götz F. Characterization of Tn917 insertion mutants of Staphylococcus epidermidis affected in biofilm formation. Infect Immun. 1996;64:277-82.

66. Lowry OH, Rosebrough NJ, Farr AL, Randall RJ. Protein measurement with the Folin phenol reagent. J Biol Chem. 1951;193:265-75.

67. Górska S, Schwarzer M, Jachymek W, Srutkova D, Brzozowska E, Kozakova H, et al. Distinct immunomodulation of bone marrow-derived dendritic cell responses to Lactobacillus plantarum WCFS1 by two different polysaccharides isolated from Lactobacillus rhamnosus LOCK 0900. Appl Environ Microbiol. 2014;80:6506-16.

68. Laemlli UK. Cleavage of structural proteins during the assembly of the head bacteriophage T4. Nature. 1970;227:680-85.

\section{Submit your next manuscript to BioMed Central and we will help you at every step:}

- We accept pre-submission inquiries

- Our selector tool helps you to find the most relevant journal

- We provide round the clock customer support

- Convenient online submission

- Thorough peer review

- Inclusion in PubMed and all major indexing services

- Maximum visibility for your research

Submit your manuscript at www.biomedcentral.com/submit
Biomed Central 